Vol. 18, n² | 2014

Varia

\title{
Violence in Ming-Qing China : An Overview
}

\author{
William T. Rowe
}

\section{(2) OpenEdition \\ Journals}

Electronic version

URL: http://journals.openedition.org/chs/1490

DOI: $10.4000 /$ chs. 1490

ISSN: 1663-4837

\section{Publisher}

Librairie Droz

\section{Printed version}

Date of publication: 1 October 2014

Number of pages: $85-98$

ISBN: 978-2-600-01854-8

ISSN: 1422-0857

Electronic reference

William T. Rowe, «Violence in Ming-Qing China : An Overview », Crime, Histoire \& Sociétés / Crime History \& Societies [Online], Vol. 18, $n^{\circ} 2 \mid 2014$, Online since 01 October 2017, connection on 01 May 2019. URL : http://journals.openedition.org/chs/1490; DOI : 10.4000/chs.1490 


\title{
Violence in Ming-Qing China: An Overview
}

\author{
William T. Rowe
}

I et us begin with a basic fact: the level of violence in late imperial China was

probably as high as that in any historical society in the world. ${ }^{1}$ Obvious as this may sound, it is easy to miss it. The entire central message of the package of literati values that we refer to as 'Confucianism', and especially after its elaboration into the so-called 'school of principle' or 'neo-Confucianism' (lixue) after the eleventh century CE, was certainly more energetic than most elite cultures in esteeming civil (wen) over military $(w u)$ values, in condemning violent behavior, and establishing peaceful, ordered, harmonious social behavior as a moral imperative. The monotony of this message has led many historians (including me) to see this constructed norm as reflective of reality, whereas in fact it was a coping mechanism for dealing with a world which, as its inhabitants well knew, was violent and disorderly.

Some have argued that there was a class dynamic at work here: whereas genuine literati would abhor violence, the lower class population was free to develop its own counter-culture, with more vigorous and combative strains. There is some truth to this, I think. There clearly was something of a 'civilizing process' underway in imperial China is which elites progressively abandoned blood sports, hunting, and the duel. But as Barend ter Haar has pointed out, the elite's progressive eschewing of violence was very selective: those literati who would not think to shoot an animal would not hesitate to beat their servants and, at times, their wives. ${ }^{2}$ Terminology describing violence was strongly and nearly uniformly condemnatory (bào, hàn, méng, héng, kuáng), but the possibility also existed to invoke these terms against the grain. A 'mad' dog was kuang, but so too might be a painter of wild originality. As early as the third century BCE the Grand Historian Sima Qian used 'baokuang' to describe popular uprisings that were brutal and violent, but also morally warranted.

Late imperial China, of course, was witness to several of the most hair-raising bloodbaths in human history. During the last years of the Ming (1368-1644), for example, very large-scale rebel movements cut swaths of slaughter across the empire; the rebel Zhang Xianzhong - 'the butcher of Sichuan' - is said to have depopulated that large and densely inhabited province by half, so that nearly a century later the governor reported that fully $80 \%$ of the population were still settlers from other provinces who had replaced the exterminated locals. The Taiping rebellion of 1851-1864, which killed by conservative estimates some thirty million

\footnotetext{
1 This article is drawn from a talk presented to the conference on 'History of Mass Violence in Russia and China', held in Helsinki in May 2012, and chaired by Pieter Spierenburg and Marianna Muravyeva. I am grateful to the chairs and the conference participants for helpful comments on that talk.

2 Haar (2000).
} 
people, was almost certainly the bloodiest civil war the world has ever seen. But it is not these events that will be my concern in this paper. Rather, we will concentrate on cultural, political, and social factors that contributed to the persistence of violence in the more routine 'prosperous times' (shengshi). Literally hundreds of thousands of cases of murder made their way up to the Qing Board of Punishments for review of the sentence, and clearly this only represented the tip of the iceberg. ${ }^{3}$

\section{CULTURAL UNDERPINNINGS OF LATE IMPERIAL VIOLENCE}

Numerous cultural features of late imperial and modern China conditioned acceptance of violence as a normal part of life. Butchering of animals, bloody religious sacrifices, executions in pubic marketplaces, and the display of severed heads, were all encountered as routine processes of childhood socialization. I personally remember leading my young children through a market in Taipei just as a butcher was cutting heads off chickens, who ran around frantically before collapsing in a pool of blood. (I feared that my children would be traumatized for life, but instead their reaction was a thrilled "Can we see that again?") The sociologist Yang $\mathrm{Su}$ describes an event from his early childhood in Guangxi province, in which a crowd of farmers armed only with blunt farm tools slowly beat an old ox to death in the field; it was, Yang claims, a life-altering event for him. ${ }^{4}$

Among the most ubiquitous cultural tropes in late imperial Chinese culture elite as well as popular - was that of the yuxia ('knight-errant'/ assassin), the silent killer who operates by his own strict personal moral code. The trope again goes back at least to the ancient historian Sima Qian, and has its modern avatars in such figures as Toshiro Mifune's ronin samurai and Clint Eastwood's 'man with no name.' A more universally accessible version of the yuxia was the haohan ('tough guy'): an affable sort characterized by his indifference to sex and money, immunity to pain, and love of murderous violence, sometimes for righteous reasons but as often simply because it is just good fun..$^{5}$ An enormous literature sprang up concerning the tough guy, eagerly consumed not only by young males, but, to a lesser extent, females as well. The countryside was strewn with martial arts academies and boxing associations (quanshe), as well as scenes of former battles and uprisings, old bandit lairs, and other 'sites of memory' commemorating violent heroes and villains of the past. A graphic 'unofficial' historiography (yeshi), aided by the emergence of cheap commercial publishing, reinforced these stories and memories.

A yet more basic cultural element in late imperial China was the 'demonic paradigm', argued by ter Haar to be probably the oldest stratum of Chinese popular religion. ${ }^{6}$ Dead souls may in select instances become gods, or in cases where they are well tended to by living descendants become benign ancestral spirits (shen). The remainder become ghosts or demons ( $g u i$ ). These demons inhabit the material world in countless numbers. They have an insatiable hunger for human flesh,

See for example the contribution in this issue by Thomas Buoye.

$4 \quad$ Yang (2011).

5 Ruhlmann (1960); Jenner (1996).

6 For various of ter Haar's explication of the "demonic paradigm," see ter Haar (1998, chapter 6; 2002, 2006). For a particularly detailed case study of the paradigm in practice, see Kuhn (1990). 
especially internal organs. Constant human effort must be devoted to warding off these hungry demons, via talismans and exorcistic rites, and to killing or smashing these supernatural predators wherever possible. (Indeed, many a local bandit in late imperial and modern China advanced his career by styling himself a 'demonslayer'.) Thus, human beings not only have a right, but an obligation based on selfpreservation, to engage in constant ongoing violence against demonic forces.

Demons are shape-shifters, and regularly appear in human form. This has several implications for social behavior. For one thing, condemned criminals in late imperial China were frequently physically abused or their clothing torn so as to make them appear demonic prior to execution. More ominously, unidentified outsiders, suspicious drifters, and even the local underclass might come to be seen by the established population as predatory demons demanding violent treatment. This could and routinely was implied to any person or groups against which one stood in opposition - they are demons, and thus their violent extermination is a moral imperative. (Ter Haar provocatively argues that this line of thinking was effectively invoked to legitimate violence against 'class enemies' during the Cultural Revolution.) The demonic paradigm was embedded in a complex corpus of Grimmlike children's tales. Scapegoating of suspicious persons as demons seems to have occurred with ever greater frequency and scale from the Ming on, invoked to identify human targets of vendetta action. In celebrated instances, the demonizing process was turned against foreign missionaries (accused of eating internal organs of Chinese children) in the so-called 'Tianjin massacre' of 1870, the series of violent anti-foreign crowd actions in the Yangzi valley in the early 1890s, and murders of Chinese Christian converts during the Boxer uprising of 1900.

David Johnson's impressive research on north China popular exorcistic drama in the late imperial era shows how this paradigm was continually reinforced and reproduced over generations. Typically as part of the New Year's celebration in rural villages, demons would come on stage, covered with blood and wearing animal parts as their costume. They would leave the stage and run through the crowd, splattering blood on members of the audience, and stealing pieces of raw meat from local storefronts. Then they would return to the stage, where they were appropriately beheaded - e.g. a pumpkin filled with animal blood was smashed over the actor's head. It was a performance suitably terrifying to all observers. ${ }^{7}$

\section{THE STATE AND VIOLENCE}

The late imperial state contributed to the culture of violence in a variety of ways. It was itself a major practitioner of extreme violence, for example in the criminal justice system, in which torture was a routine and precisely legislated part of the process. Normally, the more severe criminal penalties could not be imposed without a confession, and that confession was most often acquired as a result of judicial torture. These penalties themselves included a class of 'tormented punishments', including most notoriously the 'death by a thousand cuts' (lingchi), studied by Timothy Brook and his colleagues. ${ }^{8}$ Tormented punishments were designed to achieve destruction of

Johnson (2010).

8 Brook, Bourgon, Blue (2008). See also the contribution by Bourgon in the present issue. 
the body and hence carry the punishment over into the afterlife. They were imposed highly selectively, and constituted the terrorist-coercive component of the imperial state's tripartite strategy of rule, along with material nurturance of the people (yangmin) and moral and ritual indoctrination (jiaohua).

In its practice of warfare and counter-insurgency the state generally divided strategy into two approaches. The first was 'pacification' $(f u)$, in which the goal was to capture and execute key opposition leaders and then issue amnesty for the rank and file of their presumably deluded followers. The second was 'extermination' (jiao), which entailed annihilation of all real or suspected enemies and their family members to several decrees of relationship. For example, the loyalist general (and later high official) Li Hongzhang in 1864 summarily slaughtered at least twenty thousand Taiping prisoners of war in recaptured Suzhou. ${ }^{9}$ Extermination might even be undertaken pro-actively: upon hearing of the Taiping capture of Nanjing in 1853, the Qing governor-general at Guangzhou, several hundred miles from the battlefront, conducted a mass execution of tens of thousands of suspected rebel sympathizers in his jurisdiction - men, women, and children included. One Western observer commented on the efficiency of this process, counting some sixty-three beheadings in a single four-minute span. ${ }^{10}$ Another favored counter-insurgency technique, in increasing use after the White Lotus rebellion of the turn of the nineteenth century, was that of scorched earth (jianbi qingye), herding all trusted inhabitants of a war zone into a network of fortified villages and burning all settlements and fields outside their perimeter, to starve out the enemy.

The Qing was also a highly successful expansionist empire, by most accounts roughly doubling the territory ruled by its predecessor the Ming. This process entailed securing control over interior or frontier regions that had long been assumed to be part of 'China' but had not been effectively occupied or administered by any Chinese state - areas such as Taiwan, Hainan island, the southwest, and mountainous areas within central China itself, all occupied largely by indigenous peoples against whom new settlers and imperial administrators asserted their claims in the face of varying levels of resistance. Expansionism also took place on the borderlands, as huge territories such as the Manchu homeland itself, large stretches of Mongolia, Muslim central Asia, and Tibet were newly claimed as part of the empire. Much of this expansion was accomplished either by negotiation or by conquest of a relatively bloodless sort. But there were periodic exceptions, when a frustrated Qing state resorted to genocidal policies to speed up its incorporation project. In 1735-1736, for example, the Qing governor Zhang Guangsi decided, largely on his own, to exterminate some 18,000 men, women, and children of an indigenous population in Guizhou who had the temerity to rise in resistance to his sinification policies. In the northwestern Mongol proto-state of Zongharia, the Qianlong emperor, fed up with the protracted warfare between Zonghar and Qing from the 1690s to the 1750s, opted for the final solution: he sent in a massive military force which killed more than half a million people, deliberately emptied the land for new colonization, and effectively eliminated the Zonghar people from subsequent human history. ${ }^{11}$

\footnotetext{
$9 \quad$ Fei (2012).

10 Platt (2012).

11 Perdue (2005) Part Two.
} 
Pieter Spierenburg suggests that Western European states in the early modern era ever more effectively claimed a monopoly on the use of violence within their territories. ${ }^{12}$ Was this true of imperial China as well ? Clearly not to the same extent as in the West. The state continued to sanction private violence in a variety of ways. For one thing, private exaction of blood vengeance was legitimated by both the Ming and Qing Codes, though in highly specified and restricted circumstances. In certain times and places, lineage headmen were empowered by the state to impose both corporal and capital punishments on their deviant members. Most ubiquitously, although the state did formally claim a monopoly on military organization, local elite-led militia were tolerated in practice throughout the Ming and Qing for the primary purpose of defense against the local bandits with whom the militia formed something of a stable equilibrium. Beginning with the Qing's suppression of the Triad-led Lin Shuangwen rebellion in Taiwan in the 1780s, and ever more fundamentally in the White Lotus campaigns of the turn of the century and the Taiping campaigns of the 1850s and 1860 s, the Qing state relied upon such private militia to fight its own wars for it. One scholar, indeed, has argued that the White Lotus war might have ended years before it did if the state had been able to exert control over local private militia who were in the profitable business of claiming victories over increasingly imaginary rebel armies. ${ }^{13}$

At the same time, the Qing state in particular did maintain an impressive, very costly, highly sophisticated, and expanding mechanism for the resolution of civil disputes, at least in part for the purpose of deterring private violence. As the archival record makes clear, the amount of litigation heard on a daily basis by the all-purpose county magistrate rose progressively over time, becoming far the most time-consuming aspect of his duties. Everyone in the bureaucratic system bewailed this fact, but none seriously proposed that the state refuse to hear such disputes, and instead numerous remedies were proposed to help clear up the growing backlog of cases in all jurisdictions. As Philip Huang has demonstrated, one increasingly routine expedient was for the magistrate to convene an initial hearing for each piece of litigation, suggest what his decision might be, then propose to the litigants that they might get a more favorable settlement if they brought the case to a local elder for resolution; only if that failed would the magistrate hear the case in detail and resolve it personally. ${ }^{14}$ With the recognition that the Qing state willingly devoted such an enormous percentage of its energies to seeking peaceful and socially acceptable solutions to private disputes, one scholar has suggested that our image of that state ought to be revised from that of the harsh and arbitrary paternal disciplinarian of the 'Oriental Despotism' school, to that of a beleaguered father trying patiently to keep the peace among his sibling children. ${ }^{15}$

\section{VIOLENCE AND SOCIAL CHANGE}

The Ming and Qing eras, especially the three hundred years after the mid-sixteenth century - the period often referred to as early modern China - was one of wrenching

\footnotetext{
12 Spierenburg (2008).

13 Robinson (2001); Kuhn (1970); Dai (2009).

14 Huang (1996).

15 The suggestion is that of Peter C. Perdue, private conversation.
} 
social change. Such changes included rapid demographic growth, unprecedented levels of geographic and occupational mobility, expansion of the polity to include regions both internal and external in which the local population was other than 'Chinese', and a frenetic process of private association-building and formal social organization. ${ }^{16}$ Each of these changes had marked impacts on structures of conflict and levels of violence within the society.

The empire's population grew at least threefold over the course of the Qing alone, and most likely fivefold over the late imperial era as a whole. As James Lee and Wang Feng have demonstrated, this population growth was not exactly unplanned: it was a direct function of more relaxed social attitudes in response to perceptions of increasing economic opportunities, leading to 'preventive checks' on increased household size. Lee and Feng are keen to point out that there were several types of 'preventive checks' employed by the Qing population, including increased spacing between procreation activity, but it is also clear that the most important check was on the violent practice of infanticide. Infanticide was usually - though not exclusively - inflicted on of females. It was practiced routinely, although more extensively in times of short-term economic crisis, and was systematically adjusted as a response to changes in structures of economic opportunity. ${ }^{17} \mathrm{It}$ is not unreasonable to estimate that, at least ten percent of newborns in the Qing empire were murdered at birth, in spite of perceptions that this was a 'prosperous age' (shengshi).

The remarkable population growth during the early-modern era was well recognized by contemporaries, both within and outside the administration, and in a number of ways it contributed directly to incidence of interpersonal violence. Thomas Buoye, for example, has carefully documented the correlation of increasing population-to-land ratios with murder rates in various regions of the empire; specifically, as population pressure grew, notions of property rights became hardened, and disputes over the way these newly-conceived - and increasingly state-enforced - rights impinged upon 'moral economy' notions of patrimony and birthright, led to fatal disputes. ${ }^{18}$ Another byproduct of population growth, even in an era of somewhat relaxed practices of female infanticide, was an increasingly skewed sex ratio. The sociologist Ted Telford has demonstrated that among even relatively affluent males there was an increasingly evident inability over the course of the mid - to late Qing to fulfill the moral imperative to find a wife and carry on the patriline. ${ }^{19}$ In other words, Qing society included an increasing percentage of unmarried males - the so-called 'bare sticks' (guanggun) who were, by virtue of their lack of family obligations, prima facie a threat to a social and political order that was so explicitly based on the domestic unit. These figures, with nothing to anchor their moral behavior (wulai) and no one to whom to be held accountable (wuzhu), increasingly developed a bachelor sub-culture of their own. As chronic under-employment worsened over the nineteenth century, and especially with the massive military demobilization following the great mid-century rebellions, these rootless types increasingly formed an urban underclass of 'thugs' (pigun), engaging in intimidating street-corner martial-arts displays and public brawls. In late Qing

\footnotetext{
16 See Rowe (2002).

17 Lee, Wang (1999).

18 Buoye (2000).

19 Telford (1992).
} 
Tianjin, they emerged as a self-conscious cultural type known as the 'hunhunr', with distinctive oversized clothing and stylized ways of walking - a group reminiscent of the 'Apaches' in turn-of-the-century Paris or the 'zootsuiters' in early twentiethcentury American cities.

The increasing occupational specialization of the late imperial economy contributed in some cases to new incidents of collective violence. In one rural area of central China, for example, large groups of fishermen and farmers, both organized by lineage, fought protracted and often bloody battles for decades over the issue of whether to construct a dam at a key water outlet: the dam convenienced the fishermen but threatened flooding to the fields of the farmers. ${ }^{20}$ In cities, groups of porters and carters, finely specialized in types of carriage, fought recurring turf wars over rights-of-way and control over the cargoes at individual piers.

Yet more provocative of collective violence was the ethnic conflict brought about by much higher incidence of geographic mobility in the late Ming and Qing. Part of this was due to migration and conflict over land use. For example, south China was famous for the continuous warfare between 'Punti', who saw themselves as earlier settlers of the region, and 'Hakka', a distinctive cultural and linguistic group who were portrayed by the Punti as late-arriving interlopers. This lingering animosity was an important contributor to the outbreak of the Taiping movement - the first Taiping being largely Hakka - in the mid-nineteenth century. A more generalized social type - not as culturally distinctive as the Hakka, but like them practicing shifting agriculture and other upland occupational specialties - were the so-called 'shed people' (pengmin), who were in constant warfare with their lowland neighbors over issues such as deforestation and topsoil runoff. ${ }^{21}$

In the empire's increasingly cosmopolitan commercial cities, several scores of local-origin diaspora groupings of sojourners, both long and short-term, coexisted uneasily. Capable of impressive cross-ethnic cooperation in times of economic, social, or military threats to their common host city, they also found routine provocation for individual and collective violence. One representative example occurred in the wake of a wine-shop argument in Hankou in 1878 between two welllubricated customers speaking different local dialects: mushrooming numbers of recruits joined the eventually bloody fray, coming to the aid of their fellow natives merely on the basis of shared local dialect. ${ }^{22}$ In cities where a particular local origin group dominated the local economy, and especially where the dominant group was outsiders and the subjected one consisted of local natives, there was even more likelihood for lingering ethnic tensions to turn violent. In the Hunan rice-exporting city of Xiangtan in 1819, for example, a spike in grain prices on the local consumer market prompted native Hunanese to riot violently against the Jiangxi merchants who controlled the export trade. ${ }^{23}$

In the Qing empire, of course, the greatest latent ethnic animosity was between the majority population which saw itself as 'Chinese' (Hua or, later, Han), and the Qing conquest elite. ${ }^{24}$ Historians differ over the question of whether or not the latter group

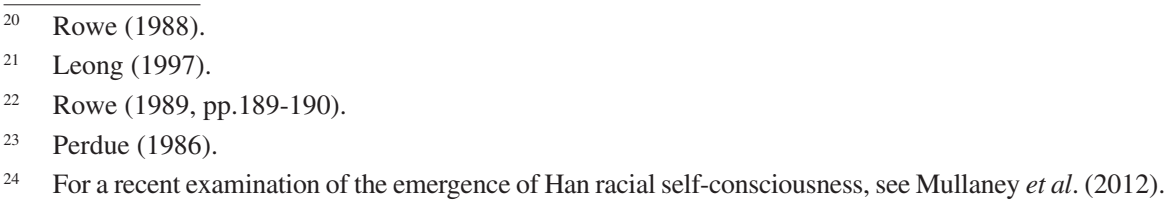


genuinely constituted a 'Manchu' nationality prior to the conquest, but most would concur that by the nineteenth century, at least, Manchu bannermen cordoned off in garrison compounds within selected cities both self-identified and were identified by their Chinese hosts as ethnically or even racially different. Under stress, animosity between the two groups could lead to violence. For instance, as British troops sailed up the Yangzi toward Nanjing during the Opium War of 1839-1842, they passed through the garrison city of Zhenjiang; stirred on by panicky administrators on both the Manchu and Chinese sides, local people of each group attacked each other, scapegoating their counterparts as potential sell-outs to the Europeans. ${ }^{25}$ The rising tide of Social Darwinist-inspired Han nationalism during the final decade of the Qing brought this racial hatred ever more threateningly to the surface. Memories of 'atrocities' and 'massacres' of local Chinese populations committed during the seventeenth century (relatively few, in fact, and often undertaken by the Qing's Han-Chinese allies) were reawakened by republication of witnesses' diaries over the empire's final decades. When the revolution finally broke out in late 1911, the enfeebled and encloistered garrison-dwellers made ready targets for "national revenge' pogroms. In one of the worst cases, an anti-Manchu genocide in the garrison city of Xi' an in October 1911 claimed the lives of an estimated ten thousand men, women, and children of the long-established local banner population. ${ }^{26}$

A direct consequence of the increased opportunities and heightened competition of the mid-Qing era of economic prosperity and population growth, I would argue, was an explosion of association-building that took many forms, but all of which were designed, at bottom, to provide their members the numerical solidarity with which to take better advantage of their changing social environment. The archetype of Chinese association-building was the lineage organization, the numbers and sizes of which grew rapidly in this era. Lineages were useful for a nearly inexhaustible range of mutual-benefit functions, but violence and coercion were prominent among them. In the lightly-governed Fujian and Taiwan, for example, lineages engaged in protracted armed feuds, often led and instigated by professional martial arts teachers. In the commercialized rice agriculture of Guangdong's Pearl River Delta, powerful armed lineages managed to effectively enslave their tenant workforce, frequently itself organized into lineage organizations for self-defense. ${ }^{27}$ Another form of popular association was the work gang (bang), organized on the basis of occupation and/or local origin, of the sort we have already seen fighting over turf and right-to-work in commercial cities. Those superfluous males unable for whatever reason to organize on the basis of kinship, trade, or local origin, gradually evolved forms of fraternity or society (hui, she), in most cases initially for self-protection, but also for violent predation, smuggling, and other forms of racketeering. Sometimes but not always these associations added a sectarian religious component to cement their solidarity. Often initially very localized and ad hoc, the most successful of these organizations - including the Triads (Tiandihui), the Society of Elder Brothers (Gelaohui), and the Green Gang (Qingbang) - came to effectively govern major

\footnotetext{
25 Elliott (1990).

26 Rhoads (2001).

27 Lamley (1990); Watson (1977).
} 
cities, regions, and transport routes, and became the progenitors of the criminal underworld of twentieth-century China. ${ }^{28}$

Finally there were bandits (tufei). Bandits came in a wide spectrum of scales, goal-structures, and intended permanency. They were to a certain extent a function of the agrarian ecology: springing into action in times of bad harvest and retreating into agrarian practice in better times, and plying the borders between county jurisdictions. Some more ambitious bandits developed persona as 'demon-slayers', as we have seen, or Robin Hood-like 'social bandit' ideologies. As David Robinson has demonstrated, tufei in practice effectively worked out a more-or-less stable equilibrium - an 'economy of violence' - in tandem with government troops and local militia and, indeed, as Elizabeth Perry has demonstrated for the ecologically fragile Huaibei region of north China, the boundary between bandit and local militia - between predator and protector - was highly conditional and permeable. ${ }^{29}$

The protectionist counterpart of the tufei was the tuhao, the local strongman. Large landholders with martial inclinations, strongmen in many isolated parts of the interior constructed hilltop forts (zhai or bao), for retreat in times of danger. Often they would invite their neighbors to join them, and temporary populations of such forts might reach the thousands. The forts might endure for centuries: some in the Dabie Shan mountains on the Hubei-Henan border were first built during the bloody Yuan-Ming transition, were inhabited again during the chaos of the late Ming and the Qing conquest, again during the Taiping invasions, and can still be observed today. Forts in the Dabie Shan also formed alliances - the 'Forty-Eight Fort League' - spanning a relatively large geographic area, and constituted in effect an autonomous region during the prolonged troubled times of the seventeenth century. ${ }^{30}$

\section{VIOLENT PROTEST}

Late-imperial urban protest assumed its most spectacular and violent form during the final reigns of the Ming, especially in the hyper-developed, increasingly socially complex, and mal-administered cities of the lower Yangzi region. Urban uprisings in this era erupted in dozens of larger and smaller cities, grew out of a wide range of grievances, and focused on differing targets, but one of the distinguishing features common to many of them was the unusual alliance against the forces of the state and of mercantile wealth on the part of lower-strata literati and urban artisans and laborers, especially in the textile trades. Three of the best-known cases can serve to illustrate this. In Hangzhou in 1582, apparently encouraged by a wage-protest mutiny in the city's military garrison, a broad alliance of workers and other renters led by a local schoolteacher rose up in protest of the labor service requirements imposed on them for service in the nightwatch, impositions from which degreeholding gentry and most property holders were exempt. Over the course of five days they raided the homes of particularly hated patricians, in several cases murdering their entire families. In 1601 in Suzhou, like Hangzhou one of the empire's major silk-producing cities, in response to the imposition of new production taxes by a

\footnotetext{
$28 \quad$ Within a rich literature, see Ownby (1996).

29 Robinson (2001); Perry (1986).

30 Rowe (2007).
} 
local administrator, and the resulting closure of many handicraft workshops by their proprietors, newly unemployed weavers and dyers, joined by lower gentry members and students of the Imperial University, rampaged through the city attacking the homes and murdering a range of officials and clerks involved in the tax-collection bureaucracy. Finally, again in Suzhou in 1626, agents of the hated court eunuch Wei Zhongxian moved in to arrest a celebrated local dissident scholar, and were greeted violently by a crowd comprised not only of the scholar's literati allies but also of workmen and the urban underclass who took this excuse to resist the hated local public security authorities. ${ }^{31}$

Protest activity was not as spectacular in the high Qing as in the tumultuous late Ming, but, despite that era's reputation for peace and harmony, it hardly disappeared altogether. Indeed, a team of scholars from Chinese People's University combing through the Qing palace archives discovered some 58 cases of violent tax resistance and no fewer than 312 cases of rent resistance between the 1660s and the 1790s, and these counted only collective actions; individual acts of violent tax and rent resistance were surely much more numerous. ${ }^{32}$ Uprisings by agrarian bondservants helped ignite the rebellions that toppled the Ming, but echoes of these continued throughout the Qing, as vestigial pockets of unfree farm laborers, often responding to rumors of imperially-declared emancipations, inflicted violent reprisals on their masters. ${ }^{33}$ Food riots were more numerous, but, as in the West, tended to be somewhat routinized, and hence less violent, if all parties kept to the customary script: seize grain from perceived hoarders, sell it publically at a 'fair price', and go home. Local officials, often privately siding with the rioters, concentrated on restoring social harmony rather than making criminal examples of hungry people. A late exception was the massive protest against the inflationary downriver export of Hunanese rice in Changsha in 1910, which forced the provincial governor to flee, drew overstrained Qing military forces to the city to put down the violence, and contributed to precipitating the successful anti-dynastic revolution the following year. $^{34}$

\section{CULTURAL RESPONSES TO VIOLENCE}

Qing administrators, elites, and commoners responded to the alarming reality of violence among them in a variety of ways. Most ubiquitous was the propaganda barrage exhorting adherence to the values of Confucian harmony - for example, mandated fortnightly public recitations of the imperial "Sacred Edict" (shengyu) instructing subjects to get along with their neighbors, pay their taxes, and be economically productive. The very routineness of this political ritual must have fostered complacence or even ridicule (though some enterprising professional Sacred Edit readers seem to have developed a repertoire of entertaining stories to illustrate each of the Edict's major points ${ }^{35}$ ). Yet the rhetoric of paternalistic 'instructing and

31 Within the large literature on late Ming urban uprisings, see Susuma (1993) and Santangelo (1993).

32 Kang-Yong-Qian shiqi chengxiang renmin fankang douzheng ziliao, Beijing: Chinese People's University Press, 1979.

33 Ye (1983).

$34 \quad$ Bin Wong (1982); Rosenbaum, 1975.

35 Mair (1984). 
civilizing' (jiaohua) had real cultural power. In an episode deeply enshrined in local history, for example, the model prefect Yu Chenglong in 1674 rode out to confront a rebel force alone, on a mule, and entreated them: "This year, hasn't the rainfall been adequate in these mountains? Haven't the crops been growing well? If so, why have you good people turned to rebellion? Why have you invited so much butchery and slaughter upon yourselves? The weather now, in midsummer, is extremely hot. At this time of year you should be attending to your aged parents, and your wives and children, in the cool comfort of your homes, rather than acting in this rash and suicidal way." The rebels, we are told, wept and laid down their arms. ${ }^{36}$

A different kind of response to massive violence was exorcism. In the wake of the Sino-Japanese War of 1894-1895, a panic spread within the population of the southeast coastal city of Quanzhou that vast armies of Chinese war dead, killed on the faraway battlefields of Manchuria and Korea, would descend as hungry ghosts to devour local citizens. An enormous city-wide exorcistic procession (jiao) was organized, led by an unusual collaboration of Confucianized imperial officials, Buddhist and Daoist clergy, and headmen of the various local commercial and artisanal guilds. It seems to have worked. ${ }^{37}$

A common means of sublimating chaotic violence was by ritualizing it. A muchcited example is the annual rock fight held in nineteenth-century Lugang, a major port city in Taiwan through which much of the trade to the mainland was funneled. On a set day, members of the four leading lineages in the city would line up on separate sides of a field at the edge of town and hurl rocks at each other, leading to injuries but rarely deaths, and then go home at the end of the day ready to live in tense but peaceful competition for the next year. ${ }^{38}$ In many central and southern Chinese cities, annual dragon boat races were held. Originating in an ancient aboriginal ritual in which the losers of the race were deliberately drowned, by the nineteenth century the dragon boat race had become a fully sinicized event in which boatmen and longshoremen from a city's various piers - frequently of differing local origins - would compete to construct the fastest boat to race across the harbor. As a competition among diverse sub-ethnic groups for which the rules were shared and collectively understood, the dragon boat race contributed to a greater sense of pan-urban communal solidarity, at least among the maritime workforce. ${ }^{39}$ But that solidarity might cut two ways : in the 1819 Xiangtan riot mentioned earlier, it was the occasion of the dragon boat festival that united the local Hunanese workforce to riot against the outsider Jiangxi merchants that dominated the local rice export trade.

In a powerful new book, Tobie Meyer-Fong surveys the way the population of the lower Yangzi valley reconstructed (shanhou) their culture and society in the wake of the mind-numbing slaughter the region had experienced during the Taiping wars. They labored at burying the dead, areas of the region being littered with decomposed corpses for years or decades. They compiled painstaking lists of 'martyrs', elevating victims of wanton violence into dedicated champions of the victorious Qing cause, and testimony to their locality's fervent imperial loyalism. They exhibited intense survivor's guilt, obsessing over loved ones they has lost, and had failed to save. They

\footnotetext{
36 Rowe (2007, p.172).

37 Wang (1995).

38 DeGlopper (1977).

39 Rowe (1989, pp. 201-206).
} 
engaged in a powerful wave of Confucian fundamentalist revivalism, struggling to understand how they had sinned, and why a benevolent Heaven would have allowed this holocaust to be visited upon them. Perhaps most importantly they attempted to domesticate the irrational slaughter by historicizing it, reducing it to a coherent historical narrative complete with heroes and villains and lessons to be learned. ${ }^{40}$ As the literary scholar David Der-wei Wang has argued, containing memories of violence into "the monster that is history" is one time-honored Chinese means of managing the unbearable personal pain of past time as actually experienced. ${ }^{41}$

\section{CONCLUDING REMARKS}

Pieter Spierenburg takes note of a consensus view that the early modern West saw a dramatic, long-term decline in homicide rates - perhaps as much as twentyfold in England, and yet more in Holland. ${ }^{42}$ Was the same true of early modern China? Even lacking reliable numbers, I don't think any scholar would claim that the parallel was anywhere close. (Certainly, if one considers infanticide as murder, no sharp protracted decline was apparent until the twentieth century, itself a very violent time in other regards).

What does this imply about Chinese culture and society? Several years ago I was presenting on a college campus my research on the centuries-long history of mass violence in the interior highland county of Macheng. A member of the audience, a distinguished anthropologist of Chinese descent, responded angrily: I was resurrecting, she argued, the Orientalist trope of 'life is cheap', the greater disrespect for human life in barbaric China versus the civilized West. Taken aback - this had certainly not been my conscious intent - I responded by recounting a televised interview I had seen with the Chinese-American playwright Frank Ching (author of the The Chickencoop Chinaman). Contrary to the anthropologist, Ching was angry about the placidity assigned by outsiders to Chinese culture: whereas male youths of other minority groups were seen as potentially violent and threatening, ChineseAmerican young men were perceived as polite, peaceable, and malleable. This was a characterization that needed to be corrected by practice, he insisted, if Chinese people were ever to be granted the dignity they deserved. For my part, I hope that by recognizing anew the brutal violence that dogged Chinese history, we can likewise restore the dignity of the populations that suffered through it.

William T. Rowe John Hopkins University Krieger School of Arts \& Sciences 340 N.Charles Street Gilman Hall Baltimore, MD, 21218 US wtrowe@jhu.edu

\footnotetext{
$40 \quad$ Meyer-Fong (2013).

41 Wang (2004).

42 Spierenburg (2008).
} 


\section{REFERENCES}

Anon. Kang-Yong-Qian shiqi chengxiang renmin fankang douzheng ziliao, Beijing, Chinese People's University Press, 1979.

Bin Wong, R., Food Riots in the Qing Dynasty, Journal of Asian Studies, 1982, 41-4.

Brook, T., Bourgon, J., Blue, G., Death by a Thousand Cuts, Cambridge MA, Harvard University Press, 2008.

Buoye, T. M., Manslaughter, Markets, and Moral Economy: Violent Disputes over Property Rights in Eighteenth-Century China, Cambridge, CUP, 2000.

Dai Y., Civilians Go into Battle: Hired Militias in the White Lotus War, 1796-1805, Asia Major, Third Series, 2009, 22, 2, pp. 145-178.

DeGlopper, D., Social Structure in a Nineteenth-Century Taiwanese Port City, in Skinner G.W. (ed.), The City in Late Imperial China, Stanford, Stanford University Press, 1977, pp. 633-650.

Elliott, M.C., Bannerman and Townsman: Ethnic Tension in Nineteenth-Century Jiangnan, Late Imperial China, 1990, 11, 1, pp. 36-74.

Fei Z., Li Hongzhang Suzhou shafeng shijian haiyuan, Qingshi yanjiu, 2012, 4.

Haar, B. ter, Ritual and Mythology of the Chinese Triads : Creating an Identity, Leiden, Brill, 1998.

Haar, B. ter, Rethinking "Violence" in Chinese Culture, in Aijmer, G., Abbink, J. (Eds), Meanings of Violence: A Cross-Cultural Perspective, Oxford, Berg, 2000, pp. 123-140.

Haar, B. ter, China's Inner Demons: The Political Impact of the Demonological Paradigm, in Woei L. C. (ed.), China's Great Proletarian Cultural Revolution: Master Narratives and Post-Mao Counternarratives, Lanham MD, Rowman \& Littlefield, 2002.

Haar, B. ter, Telling Stories: Witchcraft and Scapegoating in Chinese History, Leiden, Brill, 2006.

Huang, P.C.C., Civil Justice in China: Representation and Practice in the Qing, Stanford, Stanford University Press, 1996.

Jenner, W.J.F., Tough Guys, Mateship, and Honour: Another Chinese Tradition, East Asian History, 1996, 12, pp. 1-33.

Johnson, D., Spectacle and Sacrifice: The Ritual Foundations of Village Life in North China, Cambridge MA., Harvard East Asian Monographs, 2010.

Kuhn, P. A., Rebellion and its Enemies in Late Imperial China: Militarization and Social Structure, Cambridge MA., Harvard University Press, 1970.

Kuhn, P. A., Soulstealers: The Chinese Sorcery Scare of 1768, Cambridge MA., Harvard University Press, 1990.

Lamley, H. J., Lineage and Surname Feuds in Southern Fukien and Eastern Kwangtung under the Ch'ing, in Kwang-ching L. (ed.), Orthodoxy in Late Imperial China, Berkeley, University of California Press, 1990, pp. 255-280.

Lee, J.Z., Wang F., One Quarter of Humanity: Malthusian Myths and Chinese Realities, Cambridge MA., Harvard University Press, 1999.

Léong, S., Migration and Ethnicity in Chinese History: Hakka, Pengmin, and their Neighbors, Stanford, Stanford University Press, 1997.

Mair, V.H., Language and Ideology in the Written Popularizations of the Sacred Edict, in Johnson, D. et al. (Eds), Popular Culture in Late Imperial China, Berkeley, University of California Press, 1984, pp. 325-359.

Meyer-Fong, T., What Remains: Coming to Terms with Civil War in Nineteenth-Century China, Stanford, Stanford University Press, 2013.

Mullaney, T. et al. (Eds), Critical Han Studies: The History, Representation, and Identity of China's Majority, Berkeley, University of California Press, 2012. 
Ownby, D., Brotherhoods and Secret Societies in Early and Mid-Qing China, Stanford, Stanford University Press, 1996.

Platt, S.R., Autumn in the Heavenly Kingdom: China, the West, and the Epic Story of the Taiping Civil War, New York, Alfred A. Knopf, 2012.

Perdue, P.C., Insiders and Outsiders: The Xiangtan Riot of 1819 and Collective Action in Hunan, Modern China, 1986, 12, 2, pp. 166-201.

Perdue, P.C., China Marches West: The Qing Conquest of Central Eurasia, Cambridge MA., Harvard University Press, 2005.

Perry, E., Rebels and Revolutionaries in North China, 1845-1945, Stanford, Stanford University Press, 1986.

Rhoads, E.J.M., Manchus and Han: Ethnic Relations and Political Power in Late Qing and Early Republican China, Seattle, University of Washington Press, 2001.

Robinson, D., Bandits, Eunuchs, and the Son of Heaven: The Economy of Violence in MidMing China, Honolulu, University of Hawaii Press, 2001.

Rosenbaum, A.L., Gentry Power and the Changsha Rice Riot of 1910, Journal of Asian Studies, 1975, 34, 3, pp. 689-715.

Rowe, W., Water Control and the Qing Political Process, Modern China, 1988, 14, 4, pp. 353387.

Rowe, W., Hankow: Conflict and Community in a Chinese City, 1796-1895, Stanford, Stanford University Press, 1989.

Rowe, W., Social Stability and Social Change, in Peterson, W.J. (ed.), The Cambridge History of China, Vol.9, Part I, Cambridge, CUP, 2002, pp. 473-562.

Rowe, W., Crimson Rain: Seven Centuries of Violence in a Chinese County, Stanford, Stanford University Press, 2007.

Ruhlmann, R., Traditional Heroes in Chinese Popular Fiction, in Wright, A.R. (ed.), The Confucian Persuasion, Stanford, Stanford University Press, 1960.

Santangelo, P., Urban Society in Late Imperial Suzhou, in Cooke Johnson, L. (ed.), Cities of Jiangnan in Late Imperial China, Albany, SUNY Press, 1993.

Spierenburg, P., A History of Murder: Personal Violence in Europe from the Middle Ages to the Present, Cambridge, Polity Press, 2008.

Susuma F., Late Ming Urban Reform and the Popular Uprising in Hangzhou, in Cooke Johnson, L. (ed.), Cities of Jiangnan in Late Imperial China, Albany, SUNY Press, 1993, pp. 47-80.

Telford, T.A., Family and State in Qing China, in Institute of Modern History (ed.), Family Process and Political Process in Modern Chinese History, Taipei, Institute of Modern History, 1992, 2.921-42.

Yang S., Collective Killings in China during the Cultural Revolution, New York, CUP, 2011.

Ye X., Ming Qing Huizhou nongcun shehui yu dianpu zhi, Hefei, Anhui renmin chubanshe, 1983.

Wang Mi., Space, Administration, and Territorial Cults in Late Imperial China, Late Imperial China, 1995, 16, 1, pp. 33-78.

Wang, D.Der-wei, The Monster that is History: History, Violence, and Fiction Writing in Twentieth-Century China, Berkeley, University of California Press, 2004.

Watson, J.L., Hereditary Tenancy and Corporate Landlordism in Traditional China: A Case Study, Modern Asian Studies, 1977, 11, 2, pp. 161-182. 